\title{
Betanodavirus B2 protein triggers apoptosis and necroptosis in lung cancer cells that suppresses autophagy
}

\author{
Hsuan-Wen Chiu ${ }^{1}$, Yu-Chin Su${ }^{1}$ and Jiann-Ruey Hong ${ }^{1,2}$ \\ ${ }^{1}$ Department of Biotechnology and Bioindustry, Laboratory of Molecular Virology and Biotechnology, Institute of \\ Biotechnology, National Cheng Kung University, Tainan 701, Taiwan \\ ${ }^{2}$ Department of Biotechnology and Bioindustry, National Cheng Kung University, Tainan 701, Taiwan \\ Correspondence to: Jiann-Ruey Hong, email: jrhong@mail.ncku.edu.tw \\ Keywords: B2 protein, cell death, p53, autophagy, lung cancer cell
}

Received: July 27, $2017 \quad$ Accepted: September 21, $2017 \quad$ Published: October 06, 2017

Copyright: Chiu et al. This is an open-access article distributed under the terms of the Creative Commons Attribution License 3.0 (CC BY 3.0), which permits unrestricted use, distribution, and reproduction in any medium, provided the original author and source are credited.

\section{ABSTRACT}

The betanodavirus B2 protein targets the mitochondria and acts as a "death factor", but its effect on lung cancer cells is unknown. We examined the effect of the B2 protein on triggering apoptosis or necroptosis via P53-dependent and P53independent pathways and increased in suppression of autophagy. The B2 protein targets the mitochondria of A549 $\left(\mathrm{P}^{2} 3^{+/+}\right)$and $\mathrm{H1} 299\left(\mathrm{P}^{2} 3^{-/}\right)$lung cancer cells due to a specific signal sequence ( ${ }^{41}$ RTFVISAHAA $\left.{ }^{50}\right)$. This triggers generation of reactive oxygen species within the mitochondria, and a minor stress response in A549 cells, but a strong stress response in $\mathrm{H} 1299$ cells. We examined the molecular mechanism of this cell death pathway, and found that B2 protein induces the P53/ Bax-mediated apoptotic pathway in A549 cells, and that a P53 specific inhibitor (pifithrin-a) switches this response to RIP3-mediated necroptosis. On the other hand, B2 induces RIP3-mediated necroptosis pathway in H1299 cells, and a necroptosis inhibitor (necrostatin-1) switches this response to the apoptotic pathway. Both types of cell death signals inhibited autophagy via a tightly increased balance of beclin-1 and Bcl-2. Thus, B2 protein triggers P53-dependent apoptosis in A549 cells and ROS/ RIP3-mediated necroptosis in $\mathrm{H1299}$ cells, and crosstalk of these pathways limits initiation of autophagy. These findings provide new insights into the possible control and treatment of lung cancer.

\section{INTRODUCTION}

Betanodaviruses are the causative agents of viral nervous necrosis (VNN) in fish, an infectious neuropathological condition characterized by necrosis of the central nervous system, including the brain and retina [1]. Clinical signs include abnormal swimming behavior and darkening of the fish [2]. VNN can cause massive dying off of the larval and juvenile populations of several marine teleost species [3]. Little is known about the molecular pathogenesis of VNN.

The nodavirus genome comprises two singlestranded molecules of positive polarity, RNA1 and RNA2 that are approximately 3.1 and $1.4 \mathrm{~kb}$ in length, respectively. RNA1 encodes a nonstructural protein of approximately $110 \mathrm{kDa}$, designated RNA-dependent RNA polymerase or protein A that is vital for replication of the viral genome. RNA2 encodes a $42-\mathrm{kDa}$ capsid protein $[4,5]$ that may induce post-apoptotic necrotic cell death through a pathway mediated by cytochrome c release [6]. In RNA replication, betanodaviruses synthesize a sub-genomic RNA3 from the 3' terminus of RNA1 that encodes two proteins, B1 and B2 [1, 7, 8]. In RGNNV, B1 plays anti-necrosis functions [9]. B2 acts as a host siRNA silencing suppressor in alpha- [10-12] and beta-nodavirus [7]. Recently, the B2 protein can induce oxidative stressmediated cell death via mitochondrial targeting in vitro and in vivo [13]. 
The tumor suppressor protein P53 plays a major role in the cellular response to DNA damage and in protecting the genome from mutations. Activation of p53 can promote cell death or survival [14]. The P53 protein mediates cellular stress responses, in that it can initiate DNA repair, cell-cycle arrest, and senescence [15-18]. Importantly, P53 also regulates apoptosis, necroptosis, and autophagy [19]. When DNA repair fails, p53 initiates apoptosis by transactivating pro-/anti -apoptotic proteins that have roles in the signal transduction of apoptosis and necroptosis [20].

Apoptosis occurs normally during development and aging, and functions as a homeostatic mechanism to maintain cell populations in tissues. Apoptosis also functions as a defense mechanism, as in immune reactions or responses to cell damage from diseases or harmful agents. There are two major apoptotic pathways: the extrinsic (or death receptor) pathway and the intrinsic (or mitochondrial) pathway [21]. The extrinsic pathway is characterized by transmembrane receptor-mediated interactions, in which death receptors (members of the tumor necrosis factor [TNF] receptor gene superfamily) have a role [22]. The intrinsic pathway has a diverse array of non-receptor-mediated stimuli that produce intracellular signals, which act directly on targets within the cell, and are mitochondria-initiated events.

Recent studies indicate that necrosis is not just a series of unregulated processes, but is a series of programmed events, termed necroptosis [23]. In fact, TNF $\alpha$, FasL, and TRAIL, the same ligands that activate apoptosis, can also stimulate necroptosis. Receptor interacting protein (RIP) kinases are also crucial regulators of cell survival and death [24]. There are seven proteins in the RIP family, each of which has a kinase domain (KD). Importantly, activation of RIP1 kinase regulates the necroptotic death pathway [25].

Autophagy is a highly conserved catabolic process, in which there is degradation of proteins and organelles that promote survival or death, depending on the physiological and pathological conditions [26]. A key part of autophagy is the sequestration of proteins and organelles within double-membrane structures, termed autophagosomes. Lysosomes target the autophagosomes, which degrade them to autophagic vacuoles or autophagolysosomes. Induction of several autophagyrelated genes, including LC3, phosphatidylinositide 3-kinase, and Beclin 1 (which is regulated by Bcl-2 and Bcl-xL proteins) [27-29], initiates the formation of an autophagosome.

We previously studied the effect of B2 protein on ATP depletion-induced cell death in vitro and in vivo $[13,30,31]$ in a line of fish cells and a zebra fish model system. However, the effect of the B2 protein on the cell death pathways in lung cancer cells is still unclear. In this study, we used the novel viral B2 protein to induce different cell death pathways in A549 lung cancer cells, which express P53 (P53 $\left.{ }^{+/+}\right)$, and H1299 lung cancer cells, which do not express P53 (P53-1-), and also examined relationship of activation of these different pathways with suppression of autophagy. These data may provide new insight into the control and treatment of lung cancer.

\section{RESULTS}

\section{B2 protein targets lung cancer cell mitochondria}

The betanodavirus B2 protein targets mitochondria via a specific signal peptide $\left({ }^{41}\right.$ RTFVISAHAA $\left.^{50}\right)$ [13]. We determined if the B2 protein can also target the mitochondria of human lung cancer cell lines A549 $\left(\mathrm{P}^{+/+}\right)$and $\mathrm{H} 1299$ (P53 $\left.^{-/-}\right)$. Thus, we used fulllength EYFP-B2 and EYFP- $\triangle \mathrm{B} 2$, which has a deleted targeting region (Figure $1 \mathrm{~B}$ and $1 \mathrm{C}$ ) that further have predicted the 3D-structure of full length (1-75 aa) and B2 mitochondria targeting domain (36 aa) as a major alpha helix confirmation, and measured localization of B2 protein using MitoTracker and measurement of green fluorescence. The results show green fluorescence in the mitochondria of cells transfected with the full-length EYFP-B2 (Figure 1A and 1Ag-1Ai: A549 cells; p-r: H1299 cells). In contrast, cells of the EYFP group (Figure 1A and Figure 1Aa-1Ac: A549 cells; d-f: H1299 cells) and the EYFP- $\triangle \mathrm{B} 2$ group (Figure $1 \mathrm{~A}$ and Figure $1 \mathrm{Aj}-1 \mathrm{Al}$ : A549 cells; m-o: H1299 cells) have green fluorescence almost entirely in the cytoplasm. We also examined the mitochondrial localization of B2 by performing western blotting analysis at $48 \mathrm{~h}$ post-transfection (Figure 1D). These results confirm that $\mathrm{B} 2$ targets the mitochondria in A549 and H1299 cells that were transfected with the fulllength EYFP-B2, but not in cells of the other groups.

\section{B2 protein induces stronger ROS production in H1299 $\left(\mathrm{P53}^{-/-}\right)$cells than A549 $\left({\mathrm{P} 53^{+/+}}^{+}\right)$cells}

Previous studies of fish indicated that B2 protein targeting of mitochondria correlates with ROS production [30]. Thus, we measured B2-induced generation of ROS at $48 \mathrm{~h}$ post-transfection in both lines of cancer cells. We also determined P53 expression in A549 cells (Figure 2A and 2Aa: lane 1) and H1299 cells (Figure 2A and 2Ab: lane 1) at $48 \mathrm{~h}$ post-transfection. The results show that FLAG-B2 expression had a stronger increasing on ROS production in H1299 cells (Figure 2C, 2Cc and 2Cd) than in A549 cells (Figure 2B, 2Bc and 2Bd) based on the H2DCFDA assay that inhibited by antioxidant inhibitor NAC (Figure 2C, 2Cg and 2Ch in H1299 cells; Figure 2B, 2Bg and 2Bh in A549 cells). Relative to cells treated with NAC, there was a 4-fold increase of ROS generation in A549 cells, and a 6-fold increase in H1299 cells (Figure 2D). We also found that B2- induced ROS production upregulates P53 by $\sim 1.3$-fold in A549 cells (Figure 2E, lane 2 and 2F). Moreover, B2-induced ROS significantly increased P53 
phosphorylation on serine residue 15 (for DNA damage) and serine residue 46 (for apoptosis), but not serine residue 392 (for tumor induction) [16, 17].

\section{B2-induces apoptosis in $\mathrm{A549}\left(\mathrm{P53}^{+/+}\right)$cells and necroptosis in $\mathrm{H1299}\left(\mathrm{P53}^{--}-\right)$cells}

Next, we determined the mechanism(s) by which the B2 protein induces cell death in both lines of lung cancer cells by use of flow cytometric analysis with Annexin-VFITV and PI staining (Figure 3). The results show that B2 protein induces apoptosis in 13\% of A549 cells (Figure 3A and 3B), but induces necroptosis in $10 \%$ of H1299 cells (Figure $3 \mathrm{~A}$ and $3 \mathrm{~B}$ ).

We also found that B2 increased the expression of the pro-apoptotic gene Bax by $\sim 2.5$-fold (Figure $3 \mathrm{C}$, lane 2) in A549 cells, but not in H1299 cells (Figure 3C, lane
4). On the other hand, B2 increased the expression of Bcl-2 in H1299 cells by $\sim 4.5$-fold, but only by $\sim 20 \%$ in A1299 cells (Figure 3D). In summary, B2 protein induces Bax-mediated apoptosis in A549 cells, but induces RIP3mediated necroptosis in H1299 cells.

\section{A specific P53 inhibitor (pifithrin- $\alpha$ ) leads to B2 protein-induction of necroptosis in A549 cells}

Next, we determined the role of P53 on apoptosis and necroptosis by double staining A549 cells with PI and annexin V-FITC, and treatment with a specific inhibitor of P53 (Pifithrin- $\alpha, 30 \mu \mathrm{M}$ ) (Figure 4). The results show that Pifithrin- $\alpha$ blocked P53 activity (Figure 4A and 4Ag4Ai) and switched the cells from apoptosis (Figure 4A and 4Ad-4Af) to necroptosis (Figure $4 \mathrm{~A}$ and $4 \mathrm{Aj}-4 \mathrm{Al}$ ). Quantitative analysis of fluorescence intensity (Figure 4B)

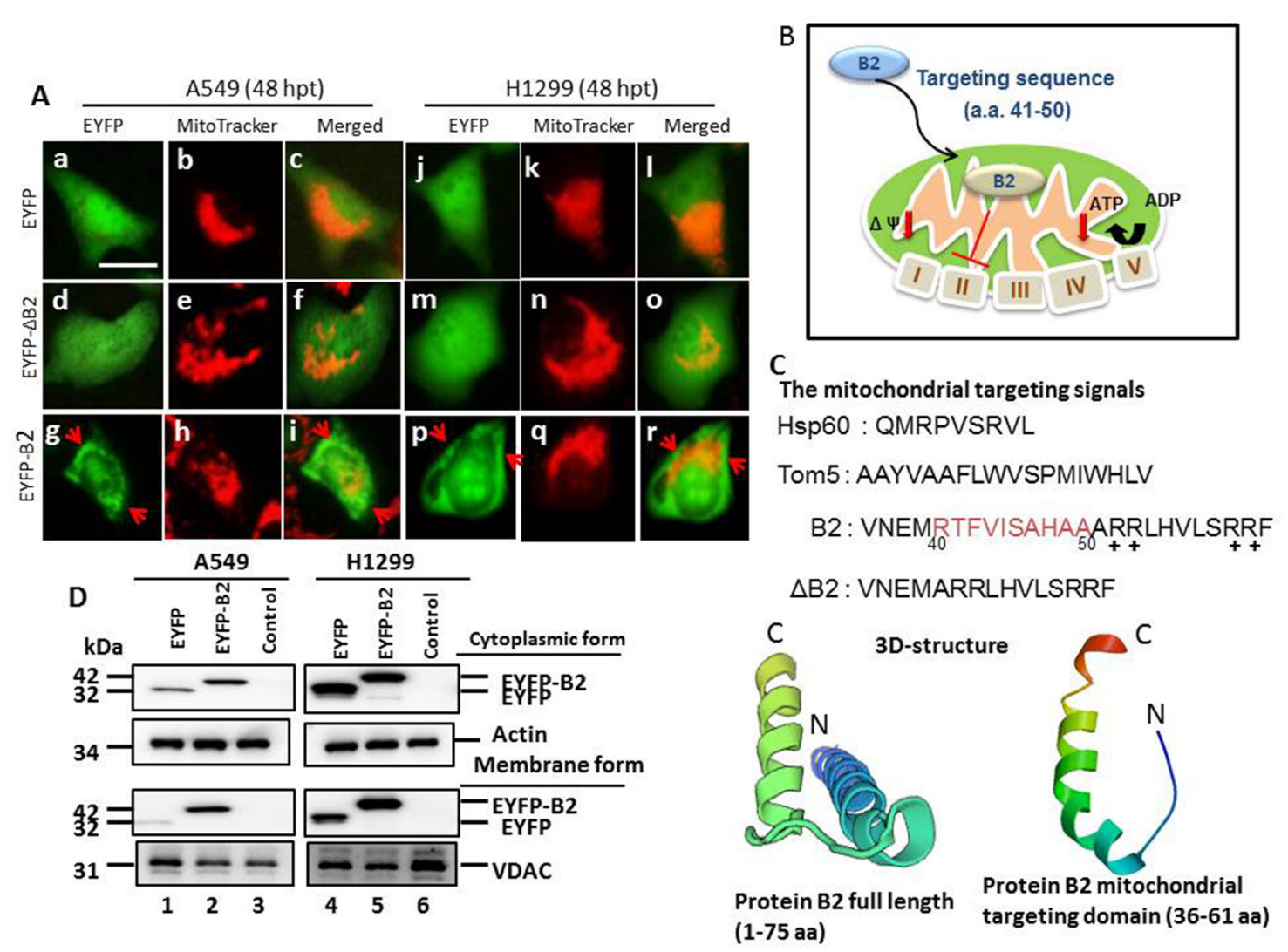

Figure 1: MitoTracker staining indicates the RGNNV B2 protein targets the mitochondria in human lung cancer cells. Analysis of mitochondrial targeting of the EYFP-B2 fusion protein at $48 \mathrm{~h}$ post-transfection indicated yellow fluorescence in $\sim 4-$ 5\% of A549 cells (A: g-i and d; indicated by arrows) and H1299 cells (A: p-r) relative to cells with EYFP (A: a-c, in A549 cells; A: j-1, in H1299 cells) and EYFP- $\triangle \mathrm{B} 2$ (del ${ }^{41}$ RTFVISAHAA ${ }^{50}$ ) (A: d-f, in A549 cells; A: m-o, in H1299 cells). Phase-contrast images of EYFP-B2 transfected cells at $36 \mathrm{~h}$ post-transfection shows that the EYFP-B2 fusion protein targets mitochondria (indicated by arrows; A: i in A549 cells; A: r in H1299 cells). Scale bar: $10 \mu \mathrm{m}$. (B) RGNNV B2 protein construct used for mitochondrial targeting. (C) Various constructs of wild type and mutant forms of the RGNNV B2 protein used to identify the mitochondrial targeting sequence. The 3D-structure of full length of RGNNV protein B2 (1-75 aa) and B2 mitochondria targeting domain (36-61 aa) alone (see Materials and Methods) were shown, and that alpha helix also existing. N: N terminus; C: C terminus. (D) Immunoblotting using monoclonal antibodies against EYFP shows the protein distribution in mitochondrial and cytosolic fractions at $48 \mathrm{~h}$ post-transfection. The internal controls were actin (cytosolic fraction) and VDAC (mitochondrial membrane fraction). EYFP alone (negative control; lanes 1 and 4); EYFP-B2 (lanes 2 and 5), controls without vector (A549 and H1299 cells; lanes 3 and 6). 
confirmed these differences were significant $(p<0.05$ for all comparisons).

We also analyzed markers of apoptosis and necroptosis in A549 cells (Figure 4C and 4D). The results show that B2 induces a $\sim 1.3$-fold increase in the proapoptotic gene Bax (Figure 4C, lane 2) and that Pifithrin- $\alpha$ treatment blocked this effect. Blockage of P53 activity was also associated with a $\sim 23 \%$ increase in RIP3 expression (Figure 4C, lane 4 and 4D). These differences were statistically significant ( $p<0.01$ for all comparisons).

\section{A specific inhibitor of necroptosis (necrostatin-1) leads to $B 2$ protein-induction of apoptosis in H1299 cells}

We also used a specific inhibitor of necroptosis (necrostatin-1, $40 \mu \mathrm{M}$ ) to determine the effect of blocking necroptosis in H1299 cells (Figure 5). Necrostatin-1 inhibits RIPK1 by blocking its association with RIP3.
Based on the PI/Annexin V double staining assay, we found that treatment of H1299 cells with necrostatin-1 inhibited necroptosis, and increased apoptosis (Figure 5A, 5Ad-5Af and 5Aj-5Al). Quantification of green fluorescence (Annexin-V-FITC) with red fluorescence (PI) confirmed that this difference was significant $(p<0.01)$.

As previously, we also examined markers of apoptosis and necroptosis in H1299 cells (Figure 5C and 5D). The results show that $\mathrm{B} 2$ protein upregulated the necrosis gene RIP3 by $\sim 1.35$-fold and Bcl-2 by $\sim 1.5$-fold (Figure 5C, lane 3 ), and that necrostatin-1 blocked this upregulation (Figure 5C, lane 4). Necrostatin-1 blocks the association of RIP1 with RIP3, leading to RIP3 instability, and cleavage from a $57-\mathrm{kDa}$ to a 55-kDa protein (Figure 5C, lane 2 vs. lane 4). On the other hand, necrostatin-1 blockage of necroptosis increased the number of H1299 cells undergoing apoptosis. Quantitation of these results indicates the differences were significant ( $p<0.01$ for all comparisons).
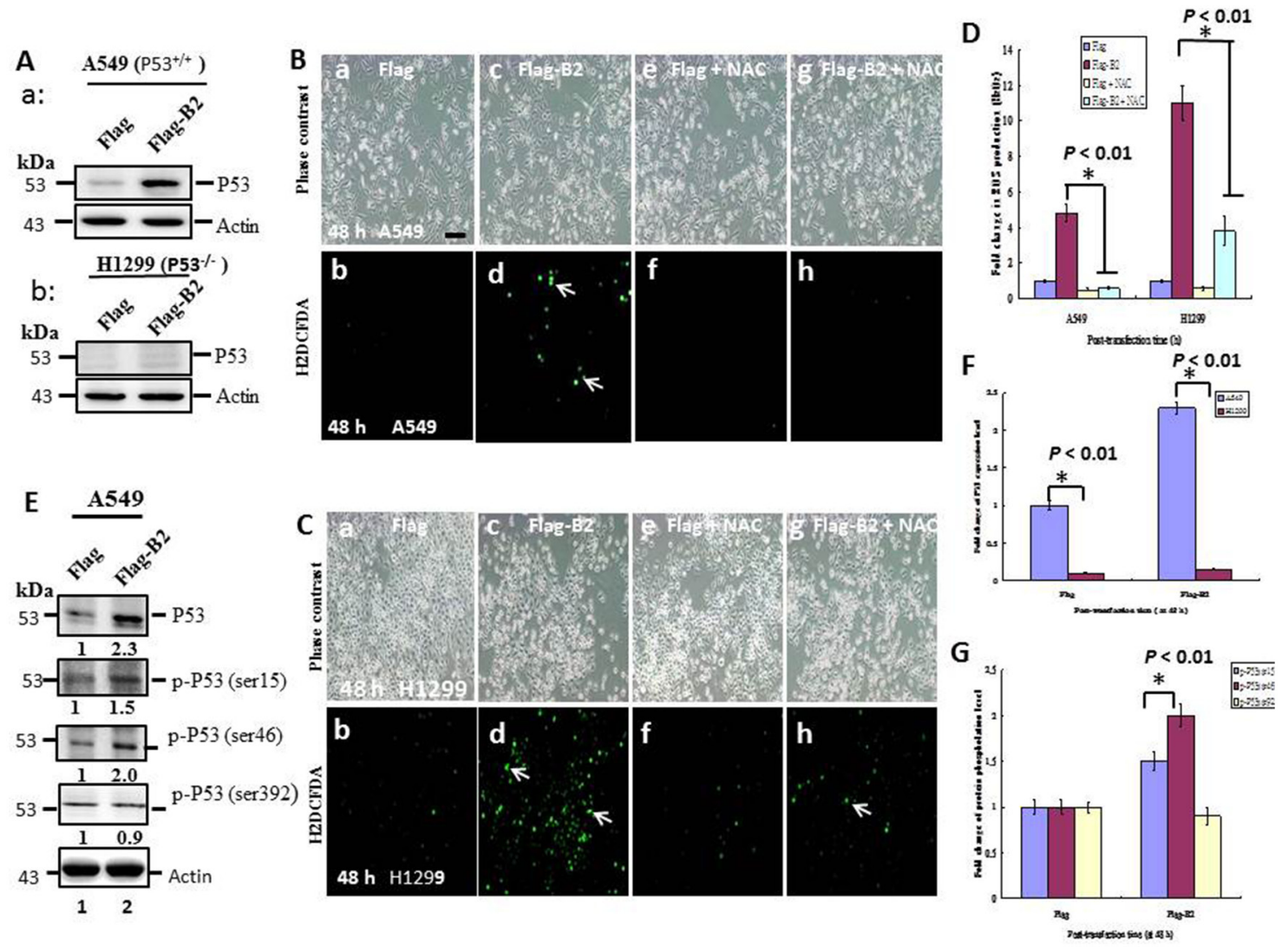

Figure 2: Targeting of B2 protein to mitochondria induces stronger ROS production in H1299 cells than A549 cells. (A) Immunoblotting shows the expression of P53 in A549 cells (P53 $\left.3^{+/+}\right)$and H1299 cells (P53---) at 48 h post-transfection, with actin used as an internal control. ROS production (arrows) by A549 cells (B) and H1299 cells (C) at 48 h post-transfection. In B and C, FLAG, negative control ( $\mathrm{a}$ and b); FLAG-B2 ( $\mathrm{c}$ and d); FLAG + N-acetylcysteine (NAC) (e and f), FLAG-B2 + NAC (g and h). Green fluorescence indicates ROS production. Scale bar $=20 \mu \mathrm{m}$. (D) Quantification of the data in B and C. Error bars represent the SEM of 3 independent experiments. All data were analyzed using a paired or unpaired Student's $t$-test, as appropriate. ${ }^{*} p<0.01$ indicates statistical significance. (E) Identification of P53 expression and phosphorylation sites in A549 cells by western blot analysis. (F and G) Quantification of the results in A and E, respectively. Error bars represent the SEM of 3 independent experiments. All data were analyzed using a paired or unpaired Student's $t$-test, as appropriate. ${ }^{*} p<0.01$ indicates statistical significance. 


\section{B2 protein regulates cell death, but limits} induction of autophagy by maintaining a balance of beclin-1 and Bcl-2 in lung cancer cells

The interaction of $\mathrm{B} 2$ protein-induced cell death with autophagy is unknown. We examined the effect of B2 protein-induced cell death on autophagy by treatment of cells with the P53 inhibitor Pifithrin- $\alpha$ or the necrotsis inhibitor necrostatin-1.

Thus, at $48 \mathrm{~h}$ post-transfection, B2 expression inhibited autophagy initiation in A549 cells (Figure 6A) and H1299 cells (Figure 6B) based on the LC3-II/ LC3-I ratio, a marker of autophagy. There was also downregulation of the autophagy regulation genes, beclin 1 and Bcl-2, in A549 cells, although there was upregulation of Bcl-2 and downregulation of beclin-1 in H1299 cells. Blockage of P53 in A549 cells increased the LC3-II/LC3-I ratio (Figure 6A, lane 4), and this correlated with increased expression of beclin1 and decreased expression of Bcl-2. In contrast, blockage of necrosis in H1299 cells is inhibted autophagy (Figure 6B, lane 4) on LC3-II/LC3-I ratio (Figure 6B, lane 4), and increased minor upregulation of Bcl-2 and beclin 1. Quantification of these results indicated the differences were significant ( $p<0.01$ for all comparisons) (Figure 6C and 6D). In summary, these experiments indicate the P53 gene has a role in supression of autophagy in A549 cells, but not in H1299 cells.
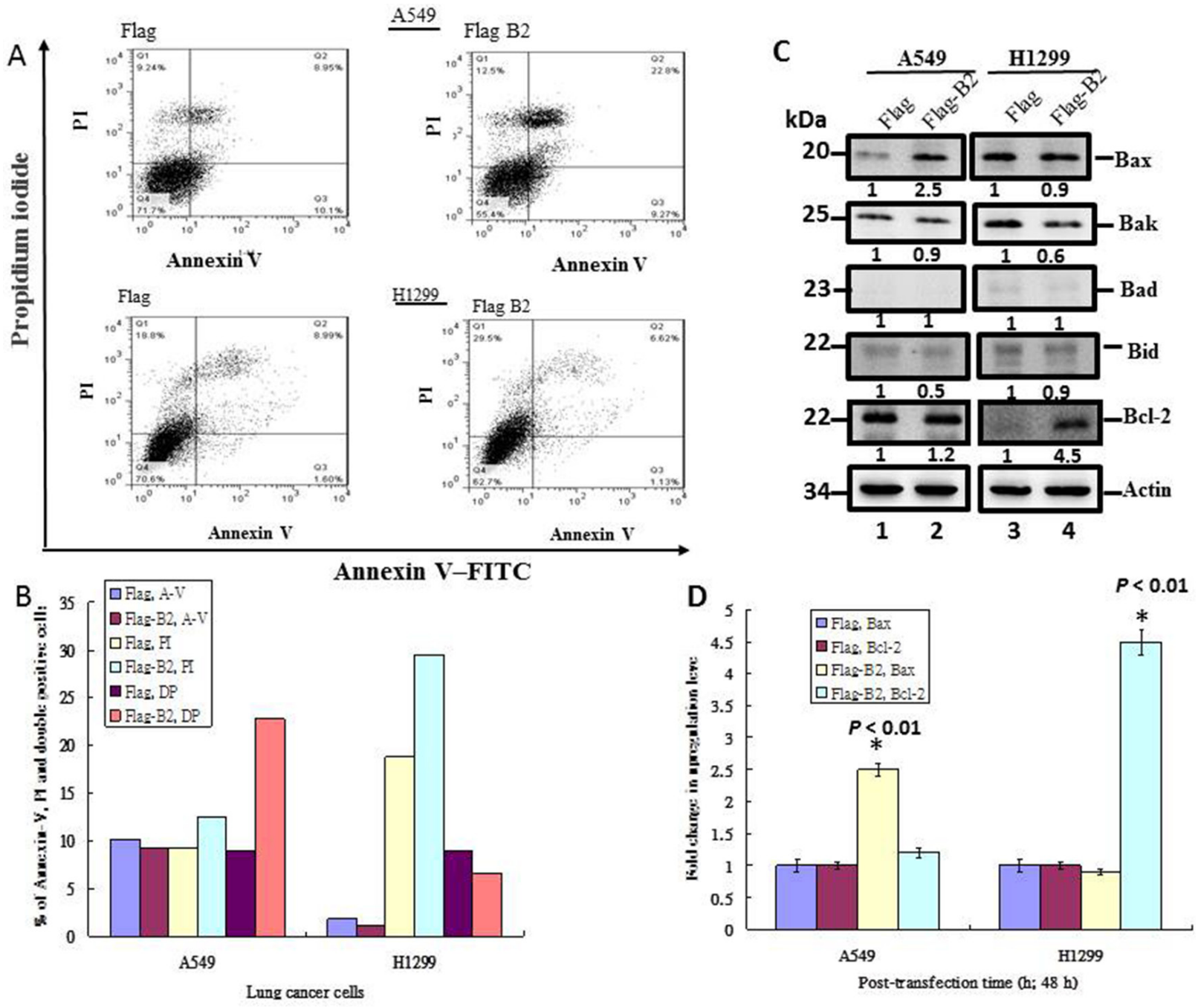

Figure 3: B2 protein induces Bax-mediated apoptosis in A549 cells, but induces RIP3-mediated necroptosis in H1299 cells. (A) Representative flow cytometry results at $48 \mathrm{~h}$ post-transfection. Fluorescence of Annexin- $\mathrm{V}$ and PI were measured in 10,000 cells. Annexin-V-FITC ${ }^{+}$cells indicate early apoptosis and $\mathrm{PI}^{+}$cells indicate late apoptotic/secondary necrosis. (B) Quantitation of the percentage of viable cells (Annexin-V-FITC ${ }^{+}$and $\mathrm{PI}^{+}$) from flow cytometry experiments. (C) Immunoblot analysis of A549 and $\mathrm{H} 1299$ cells using monoclonal antibodies against pro-apoptotic and anti-apoptotic proteins shows the expression of various forms of Bax, Bak, Bad, Bid and Bcl-2. B-actin was a loading control. (D) Quantitative analysis of the pro-apoptotic and anti-apoptotic proteins from Figure 3C. Error bars represent the SEM of 3 independent experiments. All data were analyzed using a paired or unpaired Student's $t$-test, as appropriate. ${ }^{*} P$ $<0.01$ significantly different from the control. 


\section{DISCUSSION}

B2 protein expression induces necroptosis and breakdown of mitochondria in aquatic fish cells, and this correlates with B2 targeting of mitochondria, ROS generation, and ATP depletion from complex-V $\left(\mathrm{F}_{0} \mathrm{~F}_{1}\right.$-ATP synthase). Furthermore, B2 protein induces cell death in zebrafish during the early embryonic stage (within $12 \mathrm{~h}$ post-infection) $[13,30,31]$. These results suggest that transfection experiments in which B2 protein expression is induced in other types of cells, such as lung cancer cells, may help to elucidate the mechanisms of cell death.

The present study examined the effect of the nonstructural protein B2 as a novel "death factor" that targets mitochondria and regulates apoptosis and necroptosis in lung cancer cells, depending on the presence of P53. We found that $\mathrm{B} 2$ protein targets the mitochondria of lung cancer cells, and that targeting increases to ROS

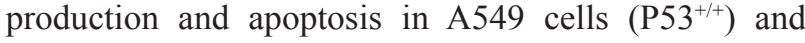
necroptosis in $\mathrm{H} 1299$ cells (P53 $3^{--}$). Our results also suggest that the presence of pathways for two types of cell death - apoptosis and necroptosis -- limits the extent of autophagy in these cells.

\section{B2 protein targets mitochondria and triggers stress signals in lung cancer cells}

Our results indicate that the $\mathrm{B} 2$ signal region was between amino acids 41-50 $\left({ }^{41}\right.$ RTFVISAHAA $\left.^{50}\right)$, and includes 10 amino acids [13] that target the mitochondria of A549 and H1299 cells (Figure 1B). This signal region is different from the signal regions of other proteins that target mitochondria (HSP60 and TOM5; Figure 1C) that protein B2 targeting domain was shown the alpha helix structure. Our results also show that removal of this signal peptide blocked the ability of B2 protein to target
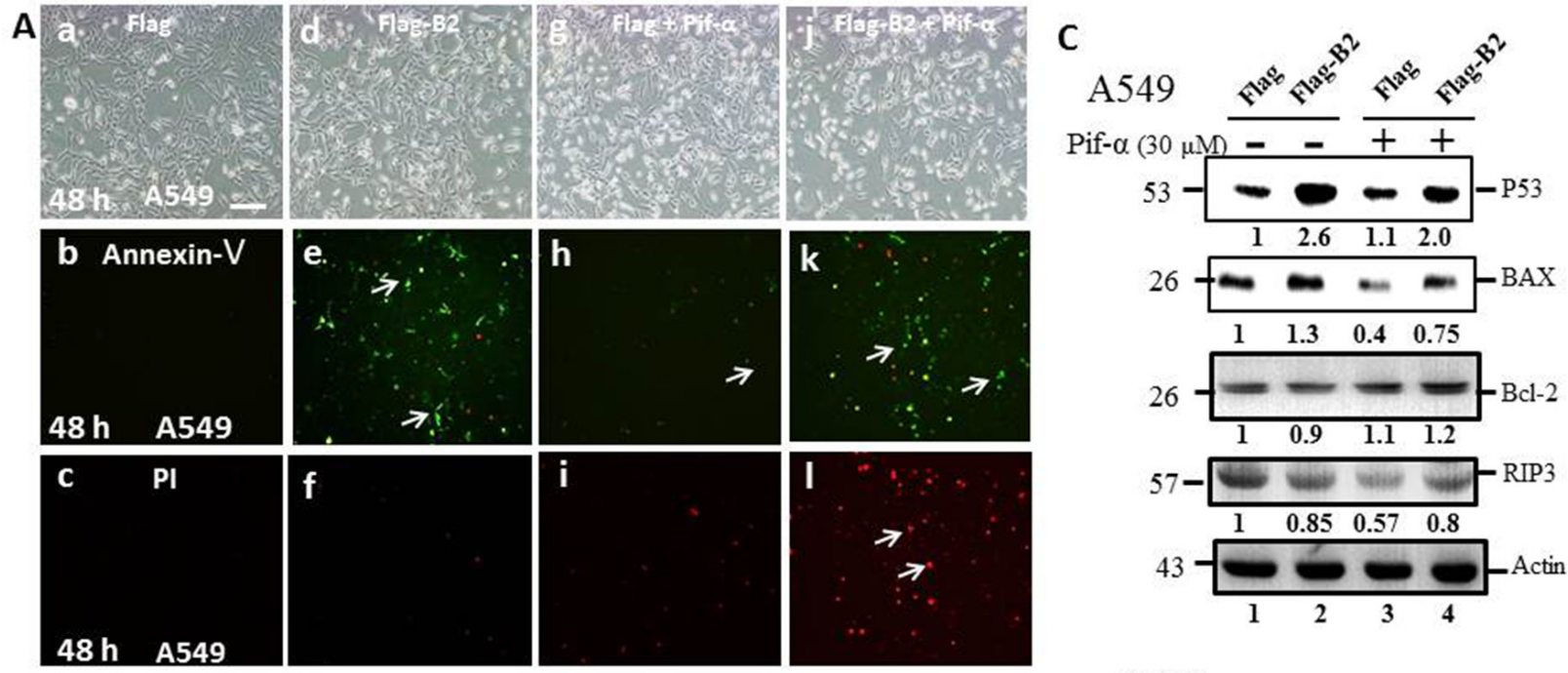

B

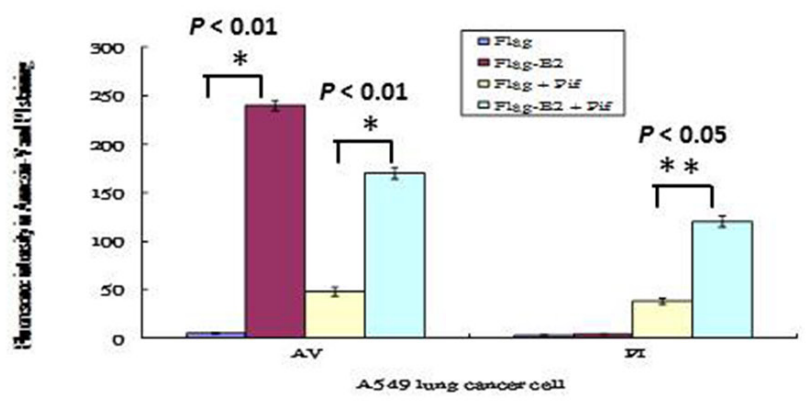

D

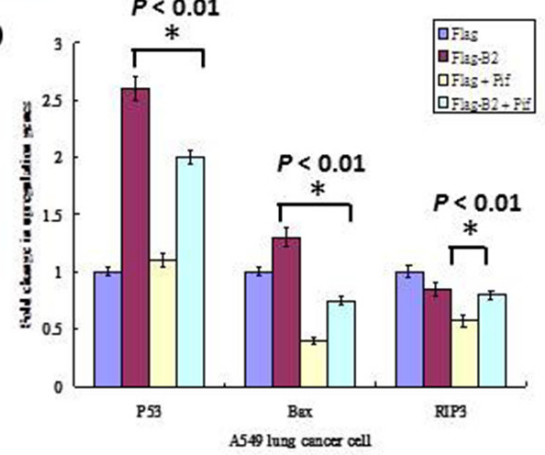

Figure 4: A P53 inhibitor blocks apoptosis and promotes necroptosis in A549 cells. (A) Phase-contrast-fluoresence microscopy of cells in the FLAG group (a-c), FLAG-B2 group (d-f), FLAG + Pif $\alpha$ group (g-i) and FLAG-B2 + Pif $\alpha(30 \mu \mathrm{M})$ group (j-1) stained with Annexin-V-FITF (b, e, h, and k) and PI (c, f, i, and l) at $48 \mathrm{~h}$ post-transformation. (B) Quantification of fluorescence of Annexin-V and PI. Error bars represent the SEM of 3 independent experiments. All data were analyzed using a paired or unpaired Student's $t$-test, as appropriate. ${ }^{*} P<0.05$ indicates statistical significance. (C) Influence of a P53 inhibitor on expression of apopotic and necrotic genes in A549 cells at $48 \mathrm{~h}$ post-transfection (western blotting). (D) Quantitation of western blotting results. Error bars represent the SEM of 3 independent experiments. All data were analyzed using a paired or unpaired Student's $t$-test, as appropriate. ${ }^{*} P<0.01$ indicates statistical significance. 
mitochondria (Figure 1A). Furthermore, we found that B2 mitochondrial targeting increases to ROS production in both cell types, although with a there was a 4-fold increase of ROS in A549 cells and an 8-fold increase of ROS in H1299 cells (Figure 2). Thus, P53 appears to have a more important role in directly regulation of oxidative stress A549 cells, but additional factors may also regulate stress in H1299 cells.

\section{B2 protein induces ROS-mediated stress signals that regulate $\mathrm{P} 53$ expression and phosphorylation}

P53 is a master controller of cellular responses, and functions as a 'guardian of the genome' [32]. Most cancers show loss of p53 function [33-37], underscoring its importance in tumor suppression. P53 alters the expression of many genes involved in specific cellular responses, including cell cycle arrest, senescence, and apoptosis [32, 36, 38-42], although there is an incomplete understanding of the factors that determine cell fate after p53 upregulation [43]. We found that B2-triggered ROS production correlates with upregulation of P53 and the downstream gene Bax (Figure 3C) in A549 cells $\left({\mathrm{P} 53^{+/}}^{+/}\right.$, but not in H1299 cells (P53-/-) (data not shown). B2-triggered ROS signals increase P53 protein phosphorylation at Ser15 (for DNA damage) and Ser46 (for apoptosis), but not at Ser93 (for proliferation) (Figure 2E-2F).

Furthermore, we found that B2 protein expression has different effects on cells with different genetic backgrounds (i.e. A549 cells (P53 ${ }^{+/+}$) and H1299 cells $\left.\left[\mathrm{P} 53^{-/-}\right]\right)$. B2 protein triggers apoptosis through P53/ Bax signaling in A549 cells (Figure 4) $[30,31]$. However,
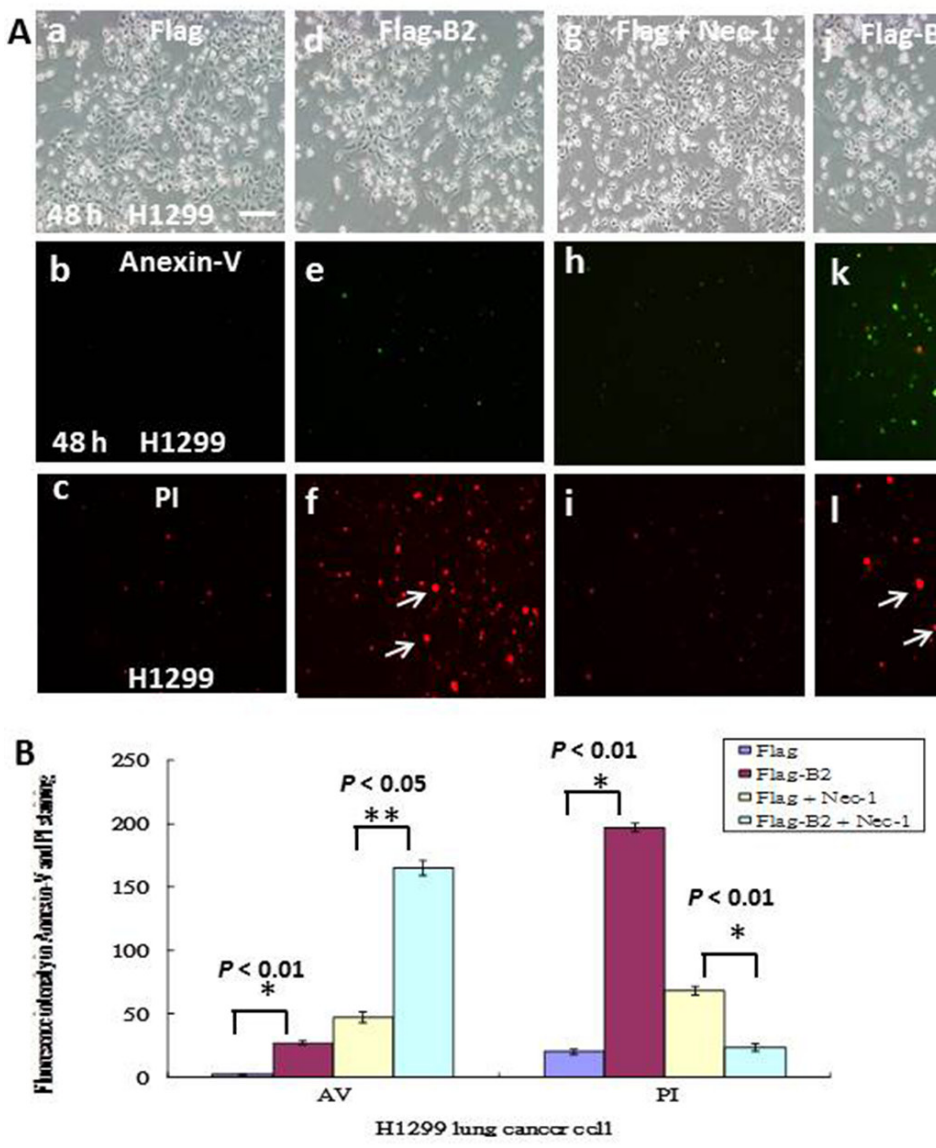
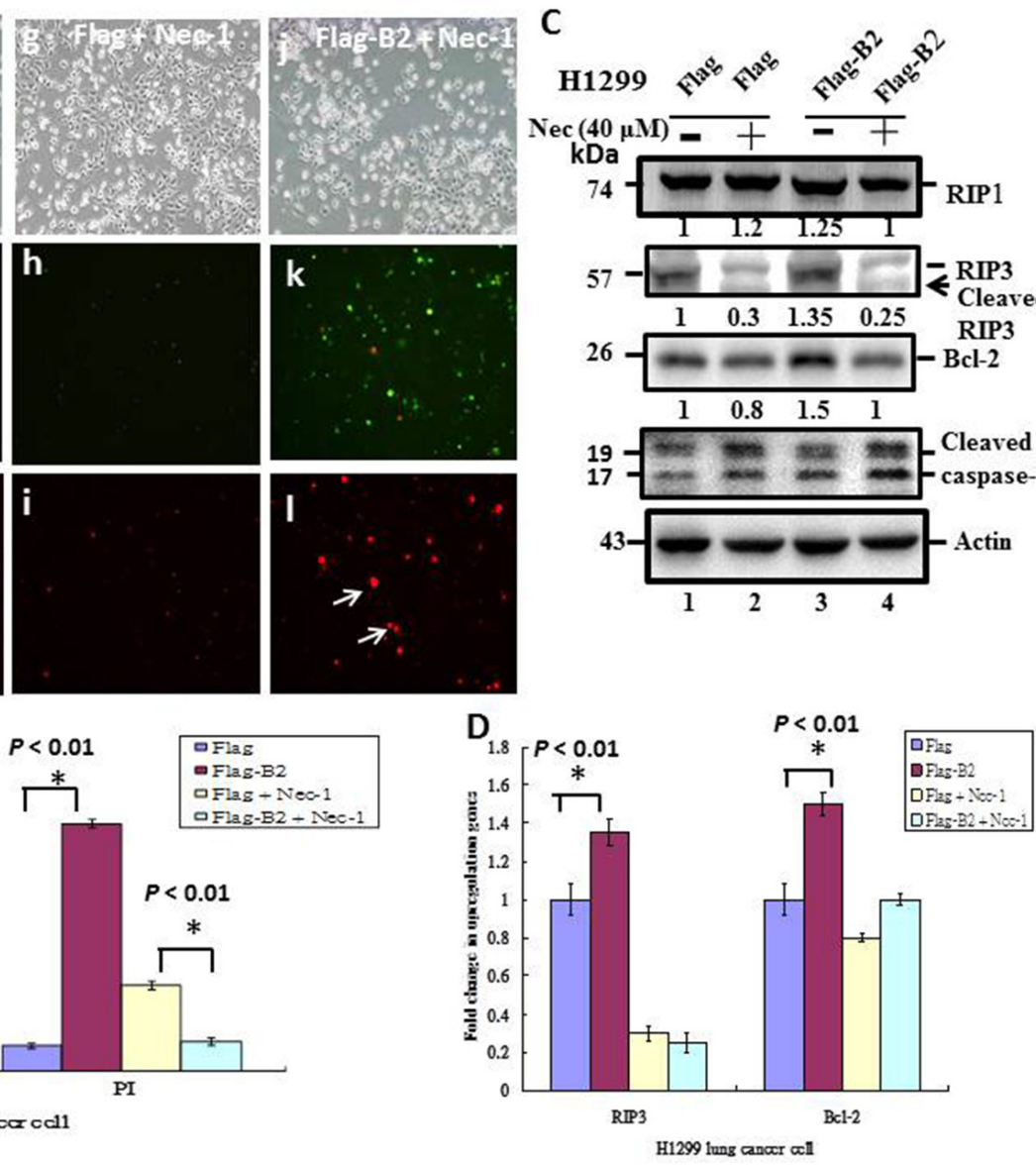

Figure 5: Blockage of RIP3 function switches B protein-transfected H1299 cells from necroptosis to apoptosis. (A) Representative phase-contrast-fluoresence images of the FLAG group (a-c), FLAG-B2 group (d-f), FLAG + Nec-1 group (g-i) and the FLAG-B2 + Nec-1 group (j-1), with staining by Annexin-V-FITC (b, e, h, and k) and PI (c, f, i, and 1) at 48 h post-transfection. (B) Quantification of FITC and PI fluorescence. Error bars represent the SEM of 3 independent experiments. All data were analyzed using a paired or unpaired Student's $t$-test, as appropriate. ${ }^{*} p<0.05$ indicates statistical significance. (C) Influence of a necrosis inhibitor on expression of apoposis- and necrosis-related genes, based on western blot analysis at $48 \mathrm{~h}$ post-transfection. (D) Quantification of the western blotting results from C. Error bars represent the SEM of 3 independent experiments. All data were analyzed using a paired or unpaired Student's $t$-test, as appropriate. ${ }^{*} p<0.01$ indicates statistical significance. 
blockage of P53 function in A549 cells by a specific inhibitor switched the mechanism to necroptosis, as indicated by downregulation of Bax and upregulation of RIP3 (Figure 4C). By contrast, we found that B2 protein triggers necroptosis via the ROS/RIP3- pathway in H1299 cells (Figure 5), and that treatment of these cells with a specific inhibitor of necroptosis switched to mechanism to apoptosis (Figure 5C), as indicated by downregulation of Bcl-2 expression.

\section{Induction of two cell death pathways by B2 protein inhibits initiation of autophagy}

In normal physiological situations, autophagy is always occurring at a basal level, and it functions as an intracellular quality-control system that maintains homeostasis by removal of superfluous and/or damaged proteins [34-46]. Autophagy and apoptosis both occur when cells are under stress [46]. Normally, autophagy precedes apoptosis and maintains cell homeostasis, with a tight crosstalk between these pathways. Some factors function in apoptosis and autophagy, such as Beclin-1 and $\mathrm{Bcl}-2$, that protein interaction on control to apoptosis or autophagy was required [47].

We found that B2 triggered P53/Bax-mediated cell death via apoptosis in A549 lung cancer cells, and that crosstalk with the autophagy pathway occurs through downregulation of Beclin-1 and Bcl-2 (Figure 6A) [46, 48]. Furthermore, inhibition of P53 by Pif- $\alpha$ switched the cells from apoptosis to autophagy via minor Beclin-1 upregulation and minor Bcl-2 downregulation. This indicates that P53-mediated apoptosis can directly regulate autophagy. On the other hand, B2 induces ROS/RIP3mediated cell death via necroptosis in H1299 cells, and also limits autophagy via minor Beclin-1 downregulation and strong Bcl-2 upregulation (Figure 6B). Then, further
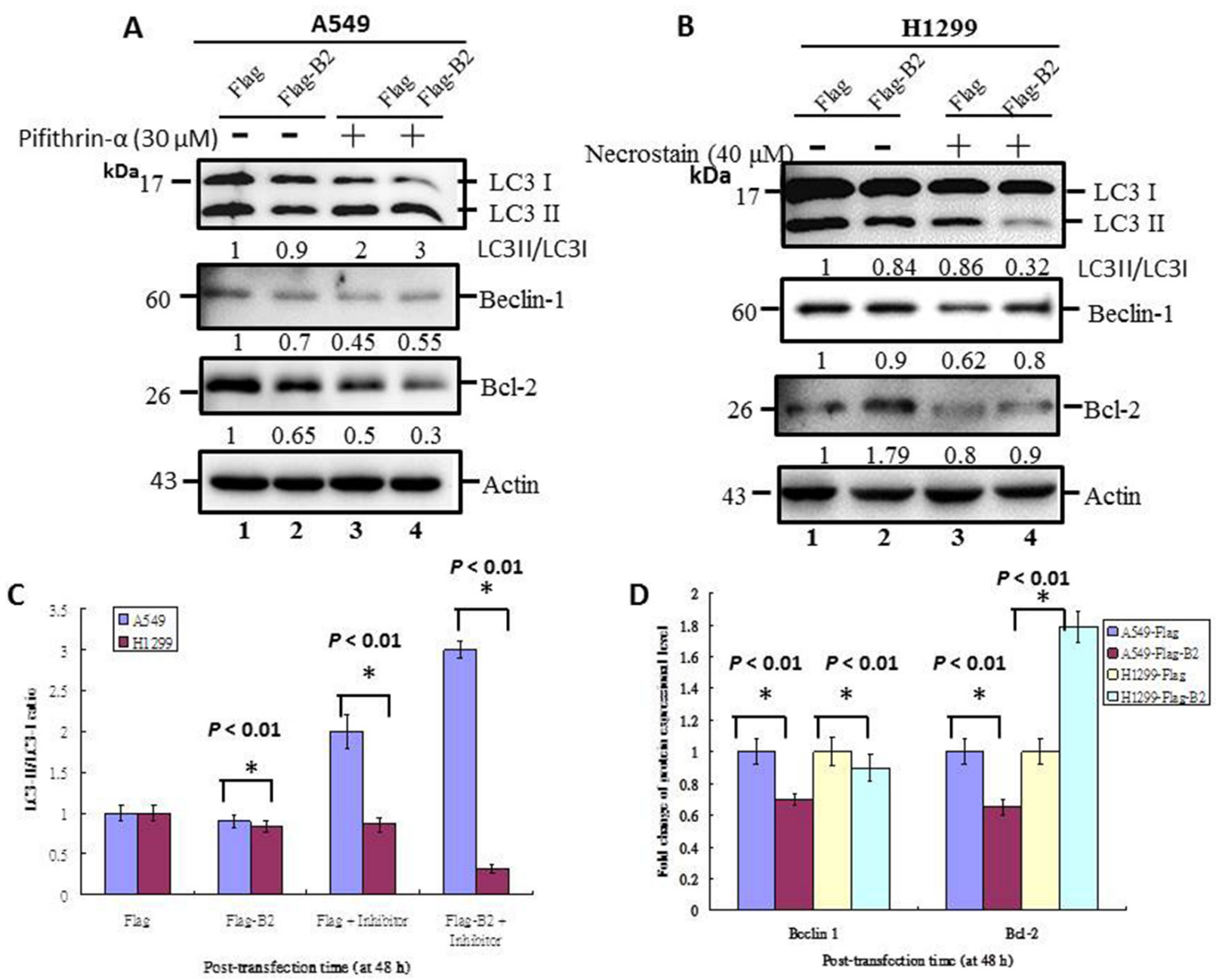

Figure 6: Crosstalk of apoptosis and necroptosis pathways limits initiation of autophagy in human lung cancer cells. Immunoblotting at $48 \mathrm{~h}$ post-transfection using monoclonal antibodies against autophagy-related proteins (LC3-I, LC3-II, Beclin-1, and Bcl-2) in A549 cells, with and without a P53 inhibitor (A) and in H1299 cells, with and without a necrosis inhibitor (B). B-actin was used as a loading control. (C and D) Quantification of the results in A and B, respectively. Error bars represent the SEM of 3 independent experiments. All data were analyzed using a paired or unpaired Student's $t$-test, as appropriate. ${ }^{*} p<0.01$ indicates statistical significance. 
necroptotic process inhibited by necroptosis inhibitor Nec1 was found that minor double upregulated the Beclin-1 and Bcl-2 expression, which necroptotic death signals is involved in autophagy regulation.

In summary, we found that the B2 protein triggers death of lung cancer cells via promotion of P53/ Bax-mediated apoptosis (A549 cells) and by ROS/ RIP3-mediated necroptosis (H1299 cells) (Figure 7). Moreover, ROS generation and metabolism has roles in the P53-dependent and P53-independent pathways [49]. Our findings also suggest that crosstalk of the apoptosis and necroptosis pathways can reduce autophagy by altering the balance of beclin-1 and Bcl-2.
If P53 activity is blocked, then Rif- $\alpha$ can switch from apoptosis to necroptosis, with only minor promotion of autophagy in A549 and H1299 cells. On the other hand, we found that blockage of necroptosis switches cells to apoptosis, but with no apparent initiation of autophagy in H1299 lung cancer cells, in contrast to A549 cells. Our findings indicate that B2 protein induces two cell death pathways - a P53-dependent pathway and a P53independent pathway. Thus, the genetic background of a cell determines which pathway is triggered, a death signals to regulate autophagy initiation between beclin-1/ Bcl-2 interaction, and this provides new insight into cancer control and therapy.

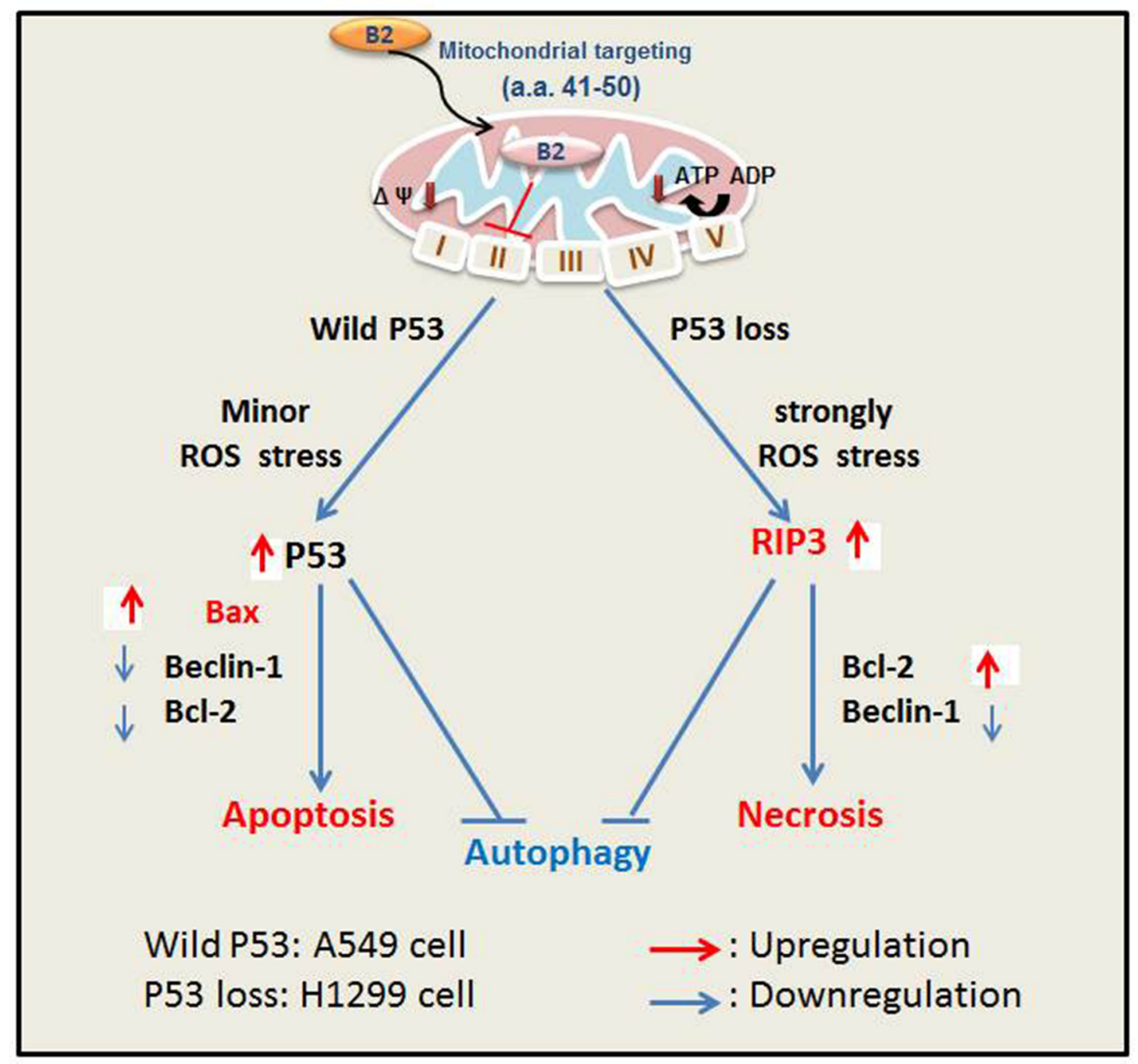

Figure 7: Hypothesized effect of protein B2-induced ROS-mediated apoptosis (A549 cells, P53+/+) and necroptosis (H1299 cells, P53-/—). Transfection of cells with RGNNV B2 protein induces ROS-mediated stress, leading to apoptosis (A549 cells) or necroptosis (H1299 cells). B2 protein first localizes to the mitochondria due to its targeting signal ${ }^{41}$ RTFVISAHAA $^{50}$ (3). B2 protein then modulates complex II activity, reducing ATP levels, and increasing ROS production. Minor ROS stress upregulates P53 and leads to apoptosis in A549 cells; strong ROS stress increases ROS/RIP3-mediated necrotic cell death in H1299 cells. Crosstalk between these two signaling pathways prevents autophagy, due to a balance of beclin-1 and Bcl-2. The P53/Bax-mediated cell death signaling limits autophagy due to downregulation of Beclin 1 and Bcl-2 in A549cells, but treated with P53 inhibitor pifithrin- $\alpha$ can enhance autophagy; ROS/RIP3 death signaling limits autophagy via upregulation of Bcl-2 and downregulation of Beclin-1 in H1299 cells, but treated with a specific inhibitor of necroptosis Nec-1 can downregulate Bcl-2 for more reducing initiation of autophagy. 


\section{MATERIALS AND METHODS}

\section{Cell culture}

Two human non-small cell lung cancer cell lines were used for experiments: the epithelial cell line A549 (ATCC, CCL-185 ${ }^{\mathrm{TM}}$; with wild type P53 expression $\left[\mathrm{P}^{5} 3^{+/+}\right]$) and line NCI-H1299 (ATCC, CRL-5803 ${ }^{\mathrm{TM}}$; without P53 expression $\left[\mathrm{P}_{53}^{--}\right]$). Cells were cultured in DMEM medium supplemented with $10 \%$ fetal bovine serum, 100 units $/ \mathrm{mL}$ penicillin, and $100 \mu \mathrm{g} / \mathrm{mL}$ streptomycin (Invitrogen) at $37^{\circ} \mathrm{C}$ in an atmosphere of 5\% $\mathrm{CO}_{2}$ in $10 \mathrm{~cm}^{2}$ Petri dishes or 6 well culture plates.

\section{Plasmid construction}

The RGNNV B2 gene with targeting sequence $\left({ }^{41}\right.$ RTFVISAHAA $\left.^{50}\right)$ or deleted fragments were cloned into the pcDNA3.1 vector (Clontech Laboratories, Palo Alto, CA), the p3XFLAG-myc-CMV-26 vector (Sigma), and the pEYFP-C1 vector (Clontech), with the enhanced yellow fluorescent protein (EYFP) [13].

\section{Cell transfection}

Polyethylenimine (PEI; Sigma Aldrich, 408727) was used as the transfection agent $[50,51]$. For cell transfection, $4 \times 10^{5}$ cells were seeded in 6 -well culture plates. On the following day, $3.2 \mu \mathrm{g}$ of recombinant plasmid was mixed with $3.2 \mu \mathrm{g}$ of PEI, and the transfection procedure was carried out according to the manufacturer's instructions.

\section{Preparation of mitochondria from B2- transfected cells}

A549 and H1299 cells were seeded in $60-\mathrm{mm}$ diameter culture dishes with $4 \mathrm{~mL}$ of medium $\left(10^{5}\right.$ cells/ $\mathrm{mL}$ ) for $24 \mathrm{~h}$. These cells were then transfected with EYFP or EYFP-B2 for $48 \mathrm{~h}$. At each change of the culture medium, $1 \mathrm{~mL}$ of medium was removed. Mitochondria were isolated by modification of a previously described protocol [30]. Briefly, cells $\left(2 \times 10^{6}\right)$ were washed with PBS and homogenized in $0.3 \mathrm{~mL}$ of mitochondria isolation buffer (0.35 M mannitol, $10 \mathrm{mM}$ HEPES, pH 7.2, 0.1\% bovine serum albumin) using a glass homogenizer. Unbroken cells and nuclei were pelleted by centrifugation ( $600 \mathrm{~g}$ for $5 \mathrm{~min}$ at $4^{\circ} \mathrm{C}$ ). Then, the mitochondrial pellet was isolated by centrifugation $\left(10,000 \mathrm{~g}\right.$ for $10 \mathrm{~min}$ at $\left.4^{\circ} \mathrm{C}\right)$ and the supernatant was collected and mixed with $25 \mu \mathrm{L}$ of $10 \times$ SDS sample buffer. Samples $(50 \mu \mathrm{L})$ were boiled and subjected to western blot analysis as previously described [13].

\section{Effect of inhibitors of p53 and necroptosis}

When lung cancer cell lines A549 and H1299 reached $50-70 \%$ confluence, they were transfected with the B2 plasmid with PEI for $4 \mathrm{~h}$. Then, the culture medium was changed and they were incubated for another $48 \mathrm{~h}$. In inhibitor experiments, cells were treated with a P53 inhibitor $(30 \mu \mathrm{M}$ Pifithrin- $\alpha[52,53]$, Sigma Aldrich, $\mathrm{P} 4359)$ or a necroptosis inhibitor $(40 \mu \mathrm{M}$ necrostatin-1 [54], Sigma Aldrich, N9037).

\section{Mitochondrial staining assay}

To track changes in mitochondrial morphology, cells were transfected as described above. After culture for 48 h, cells were stained with MitoTracker Red CM- $\mathrm{H}_{2}$ XRos (Invitrogen) in accordance with the manufacturer's instructions. Then, cells were analyzed by fluorescence microscopy, with excitation at $488 \mathrm{~nm}$ green fluorescence measured with a 515 -nm long-pass filter, and with $510 \mathrm{~nm}$ excitation and red fluorescence measured with a $590-\mathrm{nm}$ long-pass filter, as previously described [30].

\section{Intracellular ROS content of lung cancer cells}

The generation of ROS was evaluated by a fluorescent-cytometry assay based on intracellular oxidation of $\mathrm{H}_{2}$ DCFDA (Life Technologies, Carlsbad, CA, USA) [55]. Cells in the logarithmic growth phase were incubated in a 6-well plate overnight. Then, the medium was replaced with B2 transfection medium for 48 h. Cells were then washed with phosphate-buffered saline (PBS), resuspended at a concentration of $1 \times 10^{6} \mathrm{cells} / \mathrm{mL}$, and stained for $30 \mathrm{~min}$ at $37^{\circ} \mathrm{C}$. Cells were observed by fluorescence microscopy, with excitation at $488 \mathrm{~nm}$ and measurement of green fluorescence using a 515 -nm longpass filter [30].

\section{Protein extraction and western blot analysis}

After various times of incubation, cells were rinsed with $1 \times$ PBS, $3 \%$ BSA, and $0.1 \%$ Tween- 20 , then lysed with $0.05 \%$ SDS, boiled for $2 \mathrm{~min}$, and centrifuged $\left(10,000 \mathrm{~g}\right.$ at $48^{\circ} \mathrm{C}$ for $\left.10 \mathrm{~min}\right)$. The supernatant was diluted with $6 \times$ Laemmli loading buffer and boiled for $2 \mathrm{~min}$ prior to loading. Proteins were resolved by $10 \%$ sodium dodecyl sulfate-polyacrylamide gel electrophoresis, and electro-blotted onto nitrocellulose membranes. The membranes were incubated in a blocking solution (3\% BSA, $0.1 \%$ Tween-20, $1 \times$ TBS) for at least $1 \mathrm{~h}$ at room temperature (RT). Immunoblotting was performed with the following antibodies overnight at $4^{\circ} \mathrm{C}$ : anti-FLAG primary monoclonal antibodies (Sigma), Bax, Bcl2, Bid, Bak, LC3, P53, P53 ser15, P53 ser392, P53 ser46, RIP3, beclin-1, and caspase-3 (Cell Signaling Technology). Then, membranes were washed with TBS and $0.1 \%$ Tween-20, and incubated for $1 \mathrm{~h}$ at RT with the secondary antibody (horse radish peroxidase, DakoCytomation) at a dilution of 1:2000. After washing, the membranes were developed using the enhanced chemiluminiscence system (ECL, Amersham Life Sciences). The signals were 
quantified using ImageJ software and $B$-actin was used as a loading control $[13,30]$.

\section{Assays for apoptosis and necrosis}

The Annexin V-FITC/Propidium iodide (PI) flow cytometric assay was used to measure early and late apoptosis, according to the manufacturer's instructions (Annexin V-FITC/PI, Rocha). Briefly, A549 and H1299 cells were transfected with FLAG or FLAG-B2 plasmids for $48 \mathrm{~h}$ at $37^{\circ} \mathrm{C}$, then washed twice with cold PBS, and centrifuged at $1000 \mathrm{rpm}$ for $5 \mathrm{~min}$. The harvested cells were resuspended in $200 \mu \mathrm{L}$ binding buffer that contained $10 \mu \mathrm{L}$ Annexin V-FITC. After $15 \mathrm{~min}$, the cells were washed twice and resuspended in $300 \mu \mathrm{L}$ binding buffer, and $10 \mu \mathrm{L}$ of PI was added. Then, the cells were immediately analyzed by flow cytometry using a FACS Vantage cell sorter (BectonDickinson, San Jose, CA, USA). PI red fluorescence was measured using a 650-nm long-pass filter. Apoptotic and necroptotic cells have higher PI fluorescence $\left(\mathrm{PI}^{+}\right)$than intact cells $\left(\mathrm{PI}^{-}\right)$. Each analysis examined at least 10,000 cells in the gated region, based on light scattering properties. Fluorescence data are displayed on one or two major scales, as previously described [13].

\section{D-structure prediction}

SWISS-MODEL Repository (SMR) and Phyre2 web portal are a database of annotated 3D protein structure models generated by the automated SWISS-MODEL homology modeling pipeline $[56,57]$ and Phyre 2 web portal system [58]. In the 3D-strcuture prediction, the full length RGNNV B2 (1-75 aa) and B2 mitochondrial targeting domain (36-61 aa) alone sequence for comparing from either SWISS-MODEL Repository system or Phyre2 web portal system. Two systems we have found that received very similar results. Then further confirmed the 3D-structure of protein B2 to published alpha-nodavirus protein B2 in dimer form structure [59] that still received the consistent result, have shown the alpha helix structure.

\section{Statistical analysis}

All western blot images are representative of at least three independent experiments. The level of ROS production ( $\mathrm{H}_{2}$ DCFDA assay) and percentage of Annexin-V and PI-fluorescein-positive cells was determined by counting 200 cells per sample. Each result is expressed as the mean \pm SEM. Data were analyzed using the paired or unpaired Student's $t$-test, as appropriate. For comparison of group means, a $P$ value less than 0.05 was considered statistically significant.

\section{ACKNOWLEDGMENTS}

The authors are grateful to Dr. H. S. Lu (Department of Microbiology and Immunology of National Cheng
Kung University, Tainan 701, Taiwan, ROC) for providing the A549 and H1299 cell lines. This work was supported by a grant (MOST 104-2313-B-006-003) awarded to Dr. Jainn-Ruey Hong from the Ministry of Science and Technology, Taiwan, Republic of China.

\section{CONFLICTS OF INTEREST}

The authors declare no conflicts of interest.

\section{GRANT SUPPORT}

This work was supported by a grant (MOST 1042313-B-006-003) awarded to Dr. Jainn-Ruey Hong from the Ministry of Science and Technology, Taiwan, Republic of China.

\section{REFERENCES}

1. Ball L, Johnson K. Reverse genetics of nodaviruses. Adv Virus Res. 1999; 53:229-244.

2. Bovo G, Nishizawa T, Maltese C, Borghesan F, Mutinelli F, Montesi F, De Mas S. Viral encephalopathy and retinopathy of farmed marine fish species in Italy. Virus Res. 1999; 63:143-146.

3. Mori KI, Nakai T, Muroga K, Arimoto M, Mushiake K, Furusawa I. Properties of a new virus belonging to nodaviridae found in larval striped jack (Pseudocaranx dentex) with nervous necrosis. Virology. 1992; 187:368-371.

4. Munday B, Kwang J, Moody N. Betanodavirus infections of teleost fish: a review. J Fish Dis. 2002; 25:127-142.

5. Li H, Li W, Ding S. Induction and suppression of RNA silencing by an animal virus. Science. 2002; 296:1319-1321.

6. Delsert C, Morin N, Comps M. A fish encephalitis virus that differs from other nodaviruses by its capsid protein processing. Arch Virol. 1997; 142:2359-2371.

7. Wu HC, Chiu CS, Wu JL, Gong HY, Chen MC, Lu MW, Hong JR. Zebrafish anti-apoptotic protein zfBcl-xL can block betanodavirus protein alpha-induced mitochondriamediated secondary necrosis cell death. Fish Shell Immunol. 2008; 24:436-449.

8. Iwamoto T, Mise K, Takeda A, Okinaka Y, Mori K, Arimoto M, Okuno T, Nakai T. Characterization of striped jack nervous necrosis virus subgenomic RNA3 and biological activities of its encoded protein B2. J Gen Virol. 2005 ; 86:2807-2816.

9. $\mathrm{Su} \mathrm{YC}, \mathrm{Wu} J \mathrm{~L}$, Hong JR. Betanodavirus non-structural protein B2: a novel necrotic death factor that induces mitochondria-mediated cell death in fish cells. Virology. 2009; 385:143-154.

10. Chen LJ, Su YC, Hong JR. Betanodavirus non-structural protein B1: A novel anti-necrotic death factor that modulates cell death in early replication cycle in fish cells. Virology. 2009; 385:444-454. 
11. Lu R, Maduro M, Li F, Li HW, Broitman-Maduro G, Li WX, Ding SW. Animal virus replication and RNAimediated antiviral silencing in Caenorhabditis elegans. Nature. 2005; 436:1040-1043.

12. Wang X, Aliyari R, Li W, Li H, Kim K, Carthew R, Atkinson P, Ding S. RNA interference directs innate immunity against viruses in adult drosophila. Science. 2006; 312:452-454.

13. Su YC, Hong JR. Betanodavirus B2 causes ATP depletioninduced cell death via mitochondrial targeting and complex II inhibition in vitro and in vivo. J Biol Chem. 2010; 285:39801-39810.

14. Nowsheen S, Yang ES. The intersection between DNA damage response and cell death pathways. Exp Oncol. 2012; 34:243-254.

15. Bartek J, Lukas J. Chk1 and Chk2 kinases in checkpoint control and cancer. Cancer Cell. 2003; 3:421-429.

16. Oda K, Arakawa H, Tanaka T, Matsuda K, Tanikawa C, Mori T, Nishimori H, Tamai K, Tokino T, Nakamura Y, Taya Y. p53AIP1, a potential mediator of p53-dependent apoptosis, and its regulation by Ser-46-phosphorylated p53. Cell. 2000; 102:849-862.

17. Shieh SY, Ikeda M, Taya Y, Prives C. DNA damage-induced phosphorylation of p53 alleviates inhibition by MDM2. Cell. 1997; 91:325-334.

18. Stracker TH, Couto SS, Cordon-Cardo C, Matos T, Petrini JH. Chk2 suppresses the oncogenic potential of DNA replication-associated DNA damage. Mol Cell. 2008; 31:21-32.

19. Montero J, Dutta C, van Bodegom D, Weinstock D, Letai A. p53 regulates a non-apoptotic death induced by ROS. Cell Death Differ. 2013; 20:1465-1474.

20. Levine AJ. p53, the cellular gatekeeper for growth and division. Cell. 1997; 88:323-331.

21. Elmore S. Apoptosis: a review of programmed cell death. Toxicol Pathol. 2007; 35:495-516.

22. Locksley RM, Killeen N, Lenardo MJ. The TNF and TNF receptor superfamilies: integrating mammalian biology. Cell. 2001; 104:487-501.

23. Teng X, Degterev A, Jagtap P, Xing X, Choi S, Denu R, Yuan J, Cuny GD. Structure-activity relationship study of novel necroptosis inhibitors. Bioorg Med Chem Lett. 2005; 15:5039-5044.

24. Kung G, Konstantinidis K, Kitsis RN. Programmed necrosis, not apoptosis, in the heart. Circ Res. 2011; 108:1017-1036.

25. Yuan J, Kroemer G. Alternative cell death mechanisms in development and beyond. Genes Dev. 2010; 24:2592-2602.

26. Ferraro E, Cecconi F. Autophagic and apoptotic response to stress signals in mammalian cells. Arch Biochem Biophys. 2007; 462:210-219.

27. Xie Z, Klionsky DJ. Autophagosome formation: core machinery and adaptations. Nat Cell Biol. 2007; 9:1102-1109.
28. Ohsumi Y, Mizushima N. Two ubiquitin-like conjugation systems essential for autophagy. Semin Cell Dev Biol. 2004; 15:231-236.

29. Jia L, Macey MG, Yin Y, Newland AC, Kelsey SM. Subcellular distribution and redistribution of Bcl-2 family proteins in human leukemia cells undergoing apoptosis. Blood. 1999; 93:2353-2359.

30. Su YC, Chiu HW, Hung JC, Hong JR. Beta-nodavirus B2 protein induces hydrogen peroxide production, leading to Drp1-recruited mitochondrial fragmentation and cell death via mitochondrial targeting. Apoptosis. 2014; 19:1457-1470.

31. Su YC, Wu JL, Hong JR. Betanodavirus non-structural protein B2: a novel necrotic death factor that induces mitochondria-mediated cell death in fish cells. Virology. 2009; 385:143-154.

32. Nikoletopoulou V, Markaki M, Palikaras K, Tavernarakis N. Crosstalk between apoptosis, necrosis and autophagy. Biochim Biophys Acta. 2013; 1833:3448-3459.

33. Lane DP. Cancer. p53, guardian of the genome. Nature. 1992; 358:15-16.

34. Prives C. Signaling to $\mathrm{p} 53$ : breaking the MDM2-p53 circuit. Cell. 1998; 95:5-8.

35. Kubbutat MH, Jones SN, Vousden KH. Regulation of p53 stability by Mdm2. Nature. 1997; 387:299-303.

36. Prives C, Hall PA. The p53 pathway. J Pathol. 1999; 187:112-126.

37. Werness BA, Levine AJ, Howley PM. Association of human papillomavirus types 16 and 18 E6 proteins with p53. Science. 1990; 248:76-79.

38. Shay JW, Wright WE, Werbin H. Defining the molecular mechanisms of human cell immortalization. Biochim Biophys Acta. 1991; 1072:1-7.

39. Vogelstein B, Kinzler KW. p53 function and dysfunction. Cell. 1992; 70:523-526.

40. Bond J, Haughton M, Blaydes J, Gire V, Wynford-Thomas D, Wyllie F. Evidence that transcriptional activation by p53 plays a direct role in the induction of cellular senescence. Oncogene. 1996; 13:2097-2104.

41. Levine AJ. p53, the cellular gatekeeper for growth and division. Cell. 1997; 88:323-331.

42. Vousden KH. p53: death star. Cell. 2000; 103:691-694.

43. Levine AJ, Hu W, Feng Z. The P53 pathway: what questions remain to be explored? Cell Death Differ. 2006; 13:1027-1036.

44. Choi AM, Ryter SW, Levine B. Autophagy in human health and disease. N Engl J Med. 2013; 368:1845-1846.

45. Russell RC, Yuan HX, Guan KL. Autophagy regulation by nutrient signaling. Cell Res. 2014; 24:42-57.

46. Marino G, Niso-Santano M, Baehrecke EH, Kroemer G. Self-consumption: the interplay of autophagy and apoptosis. Nat Rev Mol Cell Biol. 2014; 15:81-94. 
47. Liu GB, Pei F, Yang FQ, Li LX, Amin AD, iu S, Buchan JR, Cho WC. Role of autophagy and apoptosis in non-small-cell lung cancer. Int J Mol Sci. 2017; 18:367.

48. Ravegnini G, Sammarini G, Nannini M, Pantaleo MA, Biasco G, Hrelia P, Angelini S. Gastrointestinal stromal tumors (GIST): facing cell death between autophagy and apoptosis. Autophagy. 2017; 13:452-463.

49. Reshi ML, Su YC, Hong JR. RNA viruses: ROS-mediated cell death. Int J Cell Biol. 2014; 2014:467452.

50. Ahn HH, Lee JH, Kim KS, Lee JY, Kim MS, Khang G, Lee IW, Lee HB. Polyethyleneimine-mediated gene delivery into human adipose derived stem cells. Biomaterials. 2008; 29:2415-2422.

51. Liu J, Feng M, Liang D, Yang J, Tang X. Vitamin E-Labeled polyethylenimine for in vitro and in vivo Gene Delivery. Biomacromolecules. 2016; 17:3153-3161.

52. Mohammad N, Singh SV, Malvi P, Chaube B, Athavale D, Vanuopadath M, Nair SS, Nair B, Bhat MK. Strategy to enhance efficacy of doxorubicin in solid tumor cells by methyl- $\beta$-cyclodextrin: Involvement of p53 and Fas receptor ligand complex. Sci Rep. 2015; 5:11853.

53. Reshi L, Wu HC, Wu JL, Wang HV, Hong JR. GSIV serine/ threonine kinase can induce apoptotic cell death via p53 and pro-apoptotic gene Bax upregulation in fish cells. Apoptosis. 2016; 21:443-458.
54. Xie T, Peng W, Liu Y, Yan C, Maki J, Degterev A, Yuan J, Shi Y. Structural basis of RIP1 inhibition by necrostatins. Structure. 2013; 21:493-499.

55. Chang CW, Su YC, Her GM, Ken CF, Hong JR. Betanodavirus induces oxidative stress-mediated cell death that prevented by anti-oxidants and zfcatalase in fish cells. PLoS One. 2011; 6:e25853.

56. Bienert S, Waterhouse A, de Beer TA, Tauriello G, Studer G, Bordoli L, Schwede T. The SWISS-MODEL repositorynew features and functionality. Nucleic Acid Res. 2017; 45:D313-D319.

57. Biasini M, Bienert S, Waterhouse A, Arnold K, Studer G, Schmidt T, Kiefer F, Cassarino TG, Bertoni M, Bordoli L, Schwede T. SWISS-MODEL: modelling protein tertiary and quaternary structure using evolutionary information. Nucleic Acid Res. 2014; 42:W252-W258.

58. Kelley LA, Mezulis S, Yates CM, Wass MN, Sternberg MJ. The Phyre2 web portal for protein modeling, prediction and analysis. Nat Protoc. 2015; 10:845-858.

59. Chao JA, Lee JH, Chapados BR, Debler EW, Anette Schneemann A, Williamson JR. Dual modes of RNAsilencing suppression by Flock House virus protein B2. Nat Str Mol Bio. 2005; 12:952-957. 